\title{
Impacts of integrated soil and water conservation programs on vegetation regeneration and productivity as indicator of ecosystem health in Guna-Tana watershed: evidences from satellite imagery
}

\author{
Getachew Workineh Gella ${ }^{1,2^{*}}$
}

\begin{abstract}
Background: Northern Ethiopian Highlands, including Guna-Tana watershed, have experienced profound natural resources degradation which are resulted from coupled natural and anthropogenic factors. To mitigate this problem, Ethiopian government has launched various soil and water conservation programs at different watersheds. Overall objective of this study was to analyze impacts of soil and water conservation programs on vegetation regeneration and ecosystem productivity at in Guna-Tana watershed. As prime data source, the study has utilized Moderate Imaging Spectrometer satellite bi-monthly Enhanced Vegetation Index, 8-day land surface temperature and annual Net Primary Productivity products of the past 17 years starting from 2000. Imagery was processed by using various image preprocessing and analytical techniques. Long-term trend was tested by using Sens slope estimator and Mann-Kendall's monotonic trend test. Analyzed trend was also segregated into slope and agroecology classes. More importantly, to supplement trend analysis, Vegetation Disturbance Index was developed.
\end{abstract}

Results: Results have showed that despite of long-term soil and water conservation programs, except small patches, vast expanses of the watershed have showed decrease in vegetation regeneration and primary productivity trend. This observed trend has also spatial variability across slope gradient and agroecological classes of the watershed.

Conclusion: Though there is tendency of increasing vegetation regeneration and productivity, its observed that significant positive change as a result of watershed conservation programs was very little. This indicates that for better regeneration of vegetation and maintenance of ecosystem health in a watershed, intervention programs should be revised and constraints should be assessed. Taking these into consideration, the study calls further implementation strategies which have accounted agroecology and livelihoods production system.

Keywords: Guna-Tana, Net primary productivity, ISWCP, Vegetation regeneration, Watershed

\section{Background}

Northern Ethiopian highlands are supporting large number of agricultural community whose livelihoods directly depends on farming. However, coupled with increasing

\footnotetext{
*Correspondence: getawork71@gmail.com

1 Department of Geography and Environmental Studies, Debre Tabor University, Debre Tabor, Ethiopia

Full list of author information is available at the end of the article
}

population pressure and terrain characteristics of the area, there was reported massive land degradation manifested by soil erosion and resultant nutrient depletion, forest degradation and massive expansion of agricultural land use pattern with costs of other natural cover (Gete and Hurni 2001; Hurni et al. 2010; Woldeamlak and Solomon 2013). Similarly, studies undertaken specific to Guna-Tana watershed and Upper Blue Nile basin like (Hurni et al. 2005; Mellander et al. 2013; Seleshi et al. 
2012, 2013, 2016; Adugnaw et al. 2016; Nigussie et al. 2017) have identified watershed level resource degradation problems emanated from anthropogenic and biophysical factors.

Since 1970s Ethiopian government have launched various soil and water conservation programs to curve resource degradation. Programs implemented at first phase during the Derg regime (1970s) and earlier phases of current government (1980s) were reported ineffective due to its top-down approach basically focused on physical soil erosion control measures (Osman and Sauerborn 2001; Essayas et al. 2014; Nigussie et al. 2015; Gebregziabher et al. 2016). Renovated watershed level soil and water conservation programs that have based community and its livelihoods as center piece of intervention like Community Based Natural Resources Management (CNRM), Integrated Watershed Soil and Water Conservation Program (ISWCP), Sustainable Land Management Program (SLM), Millennium Reforestation Program and Integrated Safety Net Programs (ISP) have been implemented nationally in many regions of Ethiopia including Guna-Tana watershed (Nigussie et al. 2015; Gebregziabher et al. 2016). In addition to these programs, every farm household is participating for 60 days annually in soil and water conservation works as community based campaign in Guna-Tana watershed.

The government repeatedly reported these soil and water conservation programs as effective in halting resource degradation scenarios and by reversing the trend while simultaneously improving rural livelihoods and ecosystem rehabilitation. Contrary to prospectus government reports, still there was natural vegetation degradation with opportunity cost of human induced land use pattern (Temesgen and Tesfahun 2014; Adugnaw et al. 2016). In these respect, some studies have reported as ISWCP have brought significant changes in agricultural productivity (Chisholm and Tassew 2012; Schmidt and Fanaye 2012), reduction of soil erosion and sedimentation (Kebede 2014; Nigussie et al. 2015; Molla 2016; Asnake 2017; Lemlem et al. 2017), vegetation change and positive hydrological responses (Fikir et al. 2009; Nyssen et al. 2010; Shimeles 2012), climate change adaptation (Meaza 2015), biomass recovery (Essayas et al. 2014; Lemlem et al. 2017). Though these studies have reported prospectus impacts of integrated soil and water conservation programs, still there is no any study undertaken to show long-term watershed level vegetation productivity and vegetation regeneration to see impacts of conservation programs on ecosystem health and productivity.

Remote sensing approaches were selected to harness its capability to provide spatially explicit account of ecosystem parameters (Xiaoming et al. 2010; Li et al. 2014) especially in places like Guna-Tana watershed where there is acute shortage of in situ based hydro-meteorological observations and complete absence of flux tower observing stations for ecosystem health modeling. One of the basic attributes of vegetation to measure through remote sensing for ecosystem health assessment is vigor (Eve et al. 1999; Li et al. 2014). Hence, the study has used remotely sensed net primary productivity (NPP) and enhanced vegetation index (EVI), which are repeatedly used as ecosystem productivity, health and vegetation regeneration and degradation at different ecosystems and geographic regions (Potter et al. 1993; Li et al. 2012; Feng et al. 2013; Zhou et al. 2013; Pan et al. 2014; Binyam et al. 2015; Neumann et al. 2015; Chen et al. 2017). Vegetation vigor (EVI) measures health of vegetation while NPP measures amount of net carbon assimilated to ecosystems after supporting respiration and transpiration which is common ecosystem health parameter. Therefore, the prime objective of this study was to assess impacts of integrated soil and water conservation programs on vegetation productivity and regeneration by using long-term and frequently observed satellite imagery from 2000 to mid of 2017.

\section{Methods \\ Study area}

The study site is located within $37^{\circ} 30^{\prime}-38^{\circ} 30^{\prime}$ East Longitude and $11^{\circ} 30^{\prime}-12^{\circ} 30^{\prime}$ North Latitudes (Fig. 1). It encompasses 437,632 hectares of land with elevation gradient ranging from greater than $4000 \mathrm{~m}$ above mean sea level at the tips of Guna mountain towards $1700 \mathrm{~m}$ above mean sea level at the low-laying Fogera Plains with respective vegetation heterogeneity along elevation gradient. At some parts of the watershed, slope exceeds $70 \%$, while at the outlets of watershed-Fogera Plain, there is almost level land. The study site has agro-ecological zones ranging from Kola (Tropical) towards Wurch (Afro-alpine) ecosystems, where human encroachment threatens mountain ecosystem to cause massive land use and land cover change (Adugnaw et al. 2016). At highland areas of the watershed alpine vegetation type is dominant while in lowland plains, broadleaved and riverine vegetation is common (Zerihun 1999). Because of degradation of natural forests, the community has adopted eucalyptus as alternative vegetation in private form plots and homesteads. Precipitation measurements obtained from climate hazards group infrared precipitation with stations (CHIRPS) products indicates that, long-term mean annual total rainfall ranges from $1250 \mathrm{~mm}$ /year at outlets of the watershed while it ranges to $15,440 \mathrm{~mm} /$ year at inlets of the watershed around peaks of Mount Guna. Due to this, Guna-Tana watershed is an area that contributes large amount of runoff and sediment for Blue Nile River system through Gumera and Ribb rivers 

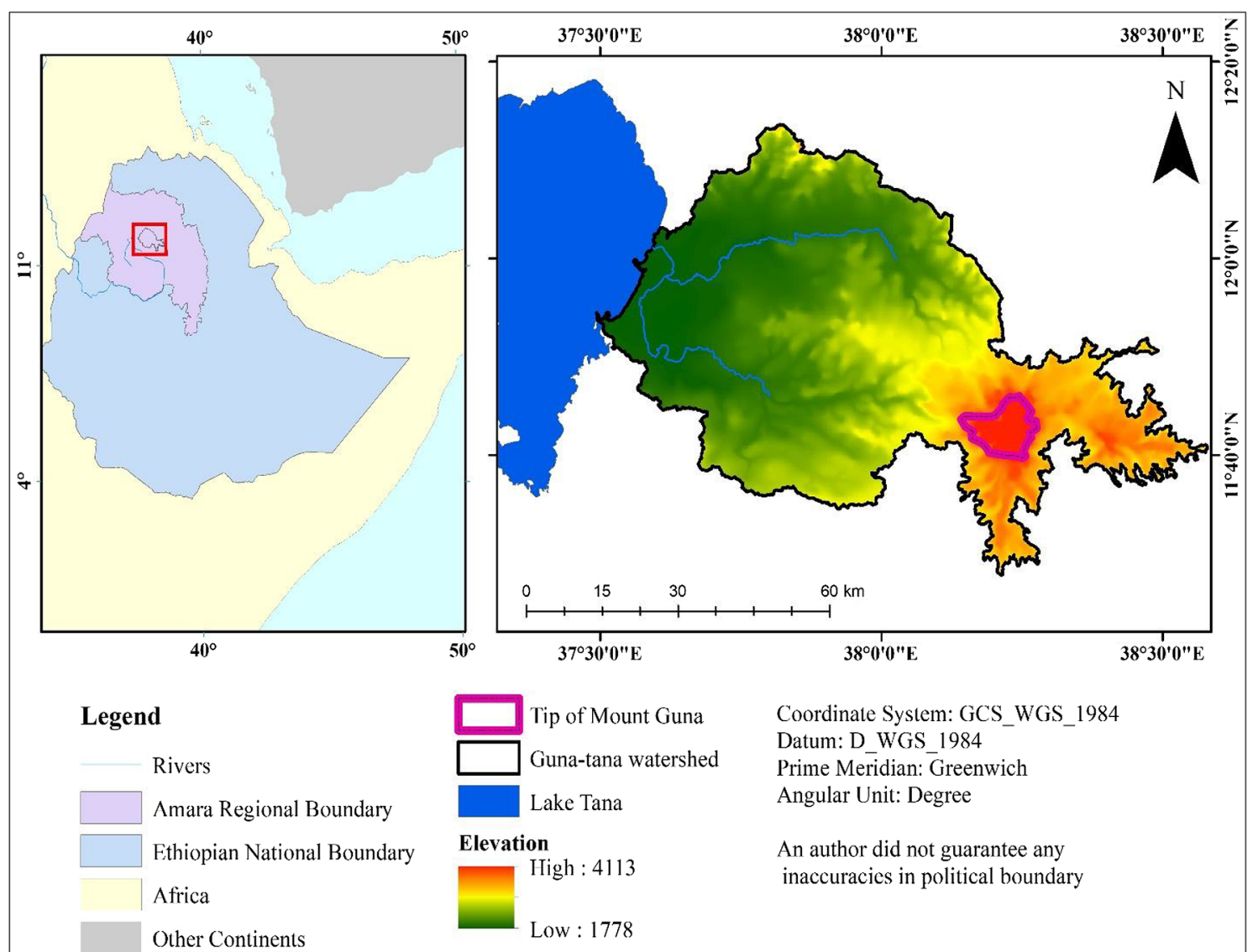

Fig. 1 Location map of the study area

(Setegn et al. 2008; Chebud and Melesse 2009). In its lower plains, there is encroaching irrigation activity and repeated flooding incidence caused by flood hazard from upper courses of the watershed (Woubet and Dagnachew 2011). Within the watershed there are five soil classes. These were Luvisols, Leptisols, Cambisols, Nitosols and vertisols with areal coverage of $67.9,1.8,9.1,0.4,20.7 \%$ of the area respectively. The watershed is experiencing advancing population increments in terms of number and density that, a single square kilometer is resided by 165 persons (CSA 2004). This made an area one of densely populated site in Ethiopia (CSA et al. 2006).

\section{Data}

The study has primarily utilized different remotely sensed imagery from different sources which are described as follows. Surface Radar Topographic Mission (SRTM) Digital Elevation Model (DEM) obtained from United States Geological Survey (USGS) website to delineate watershed boundary, identify slope gradient and agroecological classes. To see vegetation regeneration as result of watershed level integrated soil and water conservation programs, 368 tiles of 16-day Moderate Imaging Spectrometer (MODIS) EVI (MOD13Q1) composite for the past 16 years starting from third decade of $2000 \mathrm{GC}$ to mid of 2017 was accessed from Land and Atmospheric Archive System Distributed Active Archive Center (LAADS DAAC) website (ftp server). Enhanced Vegetation Index was used as robust remote sensing based vegetation vigor and regeneration index because of it does not affected by minor soil moisture differences. To see long-term changes in vegetation productivity as indicator of ecosystem health, long-term annual MODIS NPP data (MOD17A3) was downloaded from similar site with MOD13Q1. Various studies that have integrated in situ measurements from field at different ecosystems and climatic zones were validated MODIS NPP data and reported as reliable and freely available remotely sensed vegetation and ecosystem productivity data (Fensholt et al. 2006; Turner et al. 2006; Sjöström et al. 2013; Indiarto and Sulistyawati 2014; Sung et al. 2016). It incorporates principle of light use efficiency and ecological modeling approach where vegetation photosynthesis, carob fixation capacity and biome based conversion 
efficiency was accounted well (Running et al. 2004). Principally, the product is composited based on conceptualizations provided by (Monteith 1972). More importantly, vegetation disturbance accounting index was generated from integration of EVI and land surface temperature data. Therefore, in addition to EVI and NPP datasets, 736 tiles of MODIS 8 day land surface temperature composite (MOD11A2) was accessed from LAADS website.

\section{Processing and analytical approach}

Watershed boundary, which served as area of interest for this study was delineated by using ArcGIS hydrology toolbox. Downloaded MOD12A2, MOD13Q1 and MOD17A3 data was provided in Earth Observation Hierarchical Data Format (EOS-HDF) with sinusoidal projection system. These was made ready for Geographic Information Systems (GIS) softwares through format conversion and reprojection process. Format converted and re-projected data was rescaled from its quantized format by using rescaling factor provided with EOS-HDF metadata. From rescaled MODIS full scene imagery, study area of interest was extracted by using watershed boundary. More importantly these datasets have undergone a series of quality control like filtering of no data values, and removal of waterbodies from the imagery by using metadata attributes archived within the dataset.

As MODIS 16-day EVI was composited from daily EVI maximum values throughout the year, it has noise emanated from outliers and cloud contamination. This noise was removed by using Fast Fourier Transform (FFT) technique. Fourier transform converts spatial domain image into frequency domain images (real frequency, imaginary frequency, and power spectrum frequency) by using forward transformation method. Then, noise free image was constructed by using filtered frequency domain images through reverse Fourier transform (Rocchini et al. 2013). Mathematically, the representation of Fourier transforms for discrete functions in two-dimensional space can be expressed as weighted sum of sines and cosines and it is given as

$$
\mathrm{F}(u, v)=\frac{1}{N M} \sum_{x=0}^{N-1} \sum_{y=0}^{M-1} \mathrm{f}(\mathrm{x}, \mathrm{y}) e^{-2 \pi i\left(\frac{u x}{N}+\frac{v y}{M}\right)}
$$

where $u$ and $v$ are spatial frequency, $F(u, v)$ is frequency domain function, $f(x, y)$ is spatial domain function, $i$ is $\sqrt{-1}, N$ is the number of pixels in the $\mathrm{x}$-direction and $\mathrm{M}$ is the number of pixels in the $y$-direction. That is $x$ indices go from 0 to $\mathrm{N}-1$ and $\mathrm{y}$ indices go from 0 to $\mathrm{M}-1$.

Fourier sequences $F_{u}$ were multiplied by a low pass filter $(w)$, giving a filtering signal $\mathrm{w} F_{u}$ in the frequency domain. After filtering is applied, usually to reduce noises associated with high frequency components, final corrected image in spatial domain was reconstructed by using the inverse transform which is given as:

$$
f(x, y)=\sum_{u=0}^{N-1} \sum_{v=0}^{M-1} w F(u, v) e^{2 \pi i\left(\frac{u x}{N}+\frac{v y}{M}\right)}
$$

As vegetation greenness naturally experience seasonal behavior synchronized with climatic variables, before time series analysis, seasonal pattern should be removed to reduce temporal autocorrelation of time series images. De-seasoning activity was made by using standardized $\mathrm{Z}$ score time series to generate standardized anomalies, which is mathematically represented as:

$$
Z=\frac{E V I_{\text {mean }}-E V I_{i}}{E V I_{\delta}}
$$

where $E V I_{\text {mean }}$ is long-term mean EVI, $E V I_{i}$ is EVI at time $i$, and $E V I_{\delta}$ is standard deviation of EVI time series within 17 years. Though there need removal of serial correlation by pre-whitening method for Mann Kendal trend test, based on recommendation provided by Yue and Wang (2002) on the nature of data the analysis was made on standardized anomalies without pre-whitening (Bayazit and Önöz 2008). As MODIS NPP dataset is annual composite and seasonality is accounted during compositing phase, there is no need of de-seasoning operation.

Presence of log-term trend in EVI and NPP within the watershed was examined by using Mann-Kendall's nonparametric significance test (Helsel and Hirsch 1992). Mathematically, with image time series $x_{t}(t=1,2,3 \ldots n)$, each value of the series $\left(x_{t}\right)$ is compared with all subsequent values $\left(x_{t+1}\right)$ and a new image series $Z_{i}$ was created for trend test as provided in Machiwal and Jha (2012)

$$
\begin{aligned}
& Z_{i}=1 \text { for } x_{t}>x_{i} \\
& Z_{i}=0 \text { for } x_{t}=x_{i} \\
& Z_{i}=-1 \text { for } x_{t}<x_{i} \\
& \mathrm{~S}=\sum_{\mathrm{i}=1}^{\mathrm{n}-1} \sum_{\mathrm{t}=\mathrm{i}+1}^{\mathrm{n}} Z_{i}
\end{aligned}
$$

When $\mathrm{S}$ is a large positive number, later-measured values tend to be larger than earlier values and an upward trend is indicated. When $S$ is a large negative number, later values tend to be smaller than earlier values and a downward trend is indicated in selected indices. When the absolute value of $S$ is small, no trend is indicated. The test statistic Mann-Kendall $\tau$ (Thau) was computed as:

$$
\tau=\frac{S}{n(n-1) / 2}
$$


which has a range of -1 to +1 and is analogous to the correlation coefficient in regression analysis. The null hypothesis of no trend is rejected when $\mathrm{S}$ and $\tau$ are significantly different from zero. The rate of change either increasing or decreasing in EVI and NPP was calculated using the Sen's slope estimator, which is provided Donald et al. (2011) as:

$$
S_{\text {slop }}=\mathcal{M}\left(\frac{\mathrm{Y}_{j}-Y_{i}}{X_{j}-X_{i}}\right)
$$

$\mathcal{M}$ was the median for all $i<j$ and $i=1,2, \ldots, n-1$. and $j=2,3, \ldots, n$; in other words, computing the slope for all pairs of data that were used to compute $S$. The median of those slopes is the Sen slope estimator.

To supplement vegetation trend analysis yearly vegetation disturbance was computed by integrating MODIS land surface temperature and EVI. The study has adopted vegetation disturbance index designed by Mildrexler et al. (2007) and Mildrexler et al. (2009) to monitor instantaneous and non-instantaneous vegetation disturbance occurred either by anthropogenic or natural factors like wildfire and hurricane. The index is presented as:

$$
D I_{i}=\frac{\left(\frac{L S T_{i \max }}{E V I_{i \max }}\right)}{\text { multiyear mean }\left(\frac{L S T_{\max }}{E V I_{\max }}\right)_{(i-1)}}
$$

where $D I_{i}$ is vegetation disturbance for year $i, L S T_{\text {imax }}$ annula maximum temperature composite for year $i$ and $E V I_{\text {imax }}$ is annual maximum EVI composite for year $i$. The denominator is long-term mean of ratios of yearly maximum temperature and EVI with exclusion of the year under consideration. Before vegetation disturbance generation, EVI values less than 0.25 were coded as no data values. This was recommended by Huete et al. (2002) to remove non-vegetated surfaces from computation. Then annual maximum LST and EVI compositing was made on time series imagery. During compositing process years with incomplete datasets (2000 and 2017) were excluded. For the purpose of detecting presence of either positive or negative vegetation change, yearly index variabilities greater than \pm 1 standard deviations of long-term mean index were considered as disturbance. With this premise, yearly disturbance value lower than long-term disturbance is considered as increasing vegetation change and the reverse is true. for the purpose of monitoring vegetation and biomass change as a result of integrated watershed management, the index was implemented by Essayas et al. (2014) in Blue Nile Watershed.

To look into effectiveness of soil and water conservation programs across slope and agroecological classes of the watershed, slope in present rise was computed from SRTM DEM. Similarly, agroecological classes were generated from DEM of the watershed by using operational classifications provided in Hurni et al. (2016). Analytical outputs have yielded, timeseries trend, intercept and significance image layers. Overall processing and analysis was made by using HDF View, IDRISI macromodeler to automate workflows for batch processing, ArcGIS spatial analysis toolbox and $\mathrm{R}$ raster package for image analysis. Overall processing and analytical approach was presented in Fig. 2.

\section{Results and discussion}

\section{Long-term changes in vegetation regeneration}

Undertaken analysis showed that vegetation greenness in Guna-Tana watershed was flourishing in normal rainy seasons where there are sufficient crops covered precipitation and agricultural fields. With recession of precipitation, vast expanses of the study area experiences minimal EVI (Fig. 3) where precipitation deficit affects vegetation vigor.

Long term trend analysis showed that most parts of the study area (59.9\%) have experienced decreasing vegetation greenness pattern while small areal extension of Guna-Tana watershed (9.6\% of the total area) have experienced statistically significant increasing vegetation greenness $(P<0.05)$. The remaining parts of the area have shown both increasing and decreasing tendency which is not statistically significant within past 17 years (Table 1).

When we consider its spatial pattern of change, statistically significant increasing vegetation greenness pattern was observed at some patches of the watershed. These were at the outlets of watershed and outskirts of Guna Mountain (Fig. 4). This indicates that, soil and water conservation activities implemented at the watershed have spatial variability in terms of intensity and sustainability of the program. Vast expanses of lowland areas have experienced significant vegetation reduction. Lowland areas of the watershed were repeatedly reported as expansion of intensive agriculture which costs vegetation regeneration especially in dry season where crops were harvested and the field was left bare. As reported by Essayas et al. (2014), though there were massive watershed level plantation activities, large parts of Blue Nile basin have experienced decreasing biomass recovery except Lake Tana sub-basin (which is part of Guna-Tana watershed) that have positive vegetation regeneration. This was also attributed with conversion of large area to irrigated landscape with establishment of Kogga irrigation scheme and expansion of eucalyptus vegetation at privately owned farm plots.

In other way, contrary to upper parts of the watershed, soil and water conservation activities at the lower areas of the watershed was not basically focused on reforestation and area closure activities. More importantly, at 

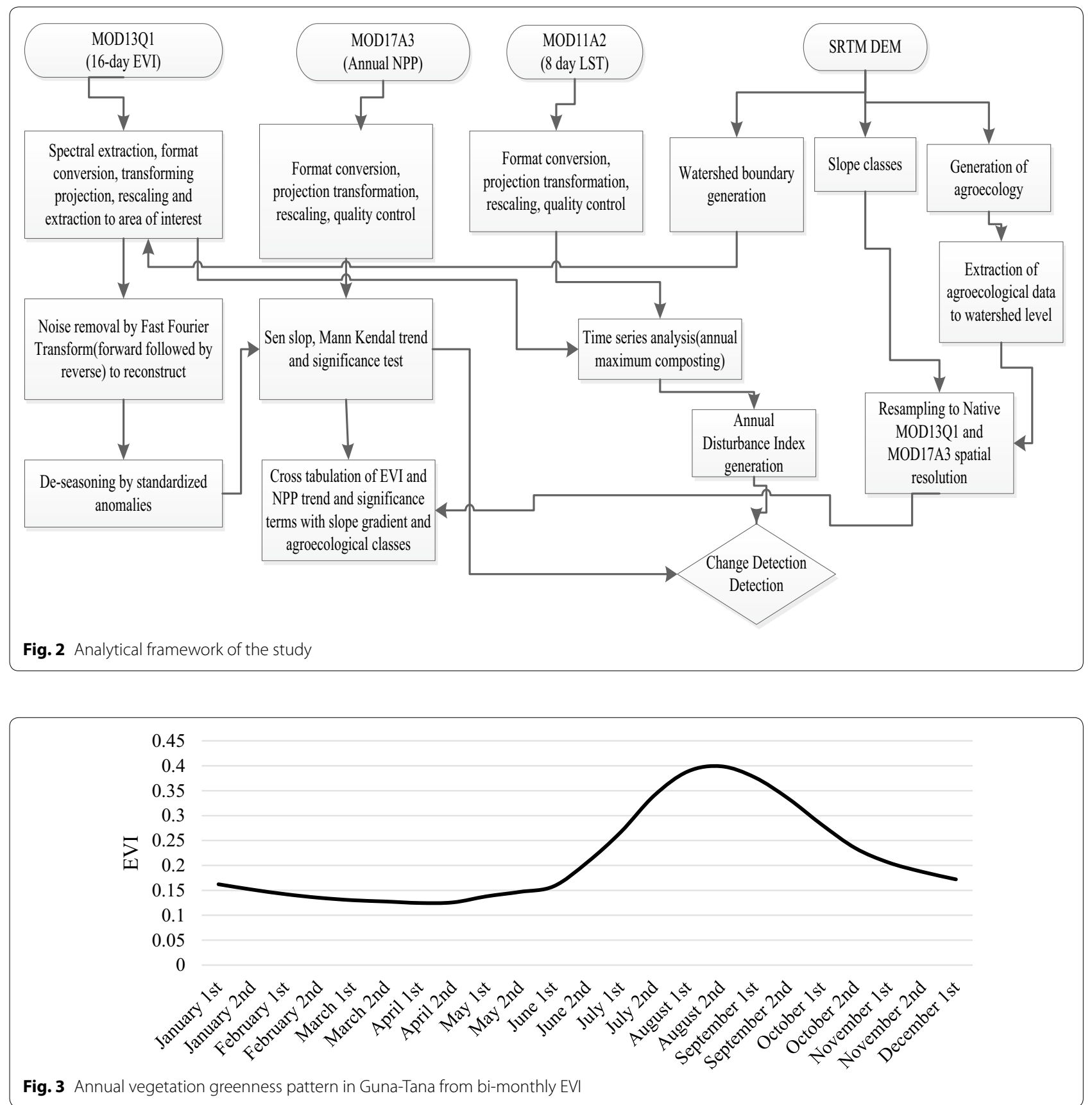

Table 1 Watershed level vegetation change trend (20002017)

\begin{tabular}{lcc}
\hline Trend & Area in hectares & $\begin{array}{l}\text { \% of total watershed } \\
\text { area }\end{array}$ \\
\hline Significant increase & $42,047.0$ & 9.6 \\
Significant decrease & $262,324.9$ & 59.9 \\
Non-significant increase & $53,549.3$ & 12.2 \\
Non-significant decrease & $79,721.6$ & 18.2 \\
Total & $437,643.0$ & 100.0 \\
\hline
\end{tabular}

Mount Guna and its surrounding, there is strict conservation measures including closure activities and relocation of resident farm households for alpine ecosystem regeneration and biodiversity conservation. A study by Teferi et al. (2015) also reported that long-term spatiotemporal variability of either vegetation greenness or browning was caused by differences by watershed management practices, establishment of plantation agriculture and settlement programs that clear natural vegetation. 


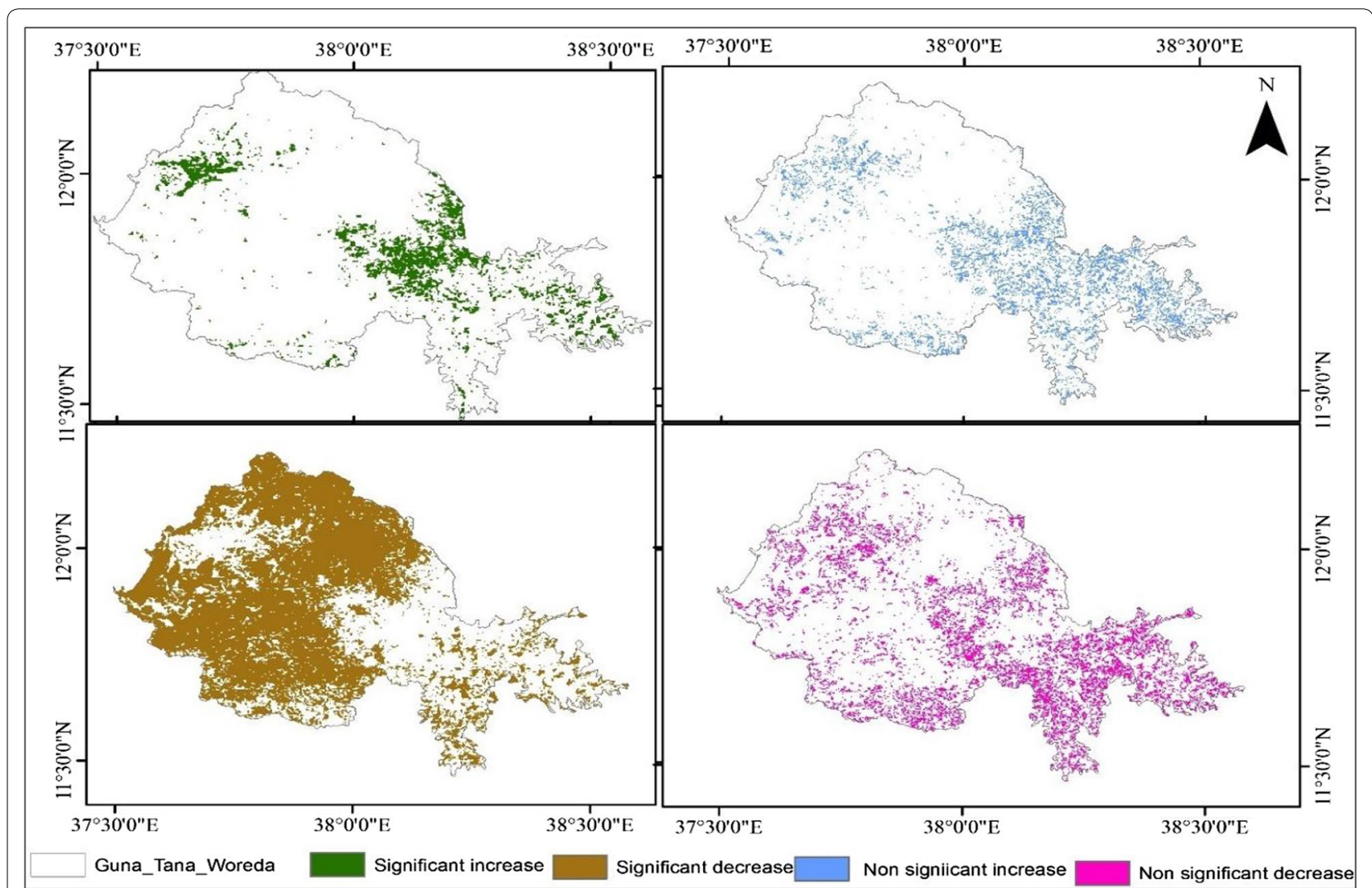

Fig. 4 Spatial patterns of trends in vegetation regeneration in Guan-Tana watershed

\section{Changes in net primary productivity}

In the past 14 years, NPP have shown spatial and temporal variability. As per these, undertaken analysis showed that, within the watershed annual amount of carbon assimilated to biosphere (NPP) ranges from $2340.3 \mathrm{~kg} \mathrm{C} \mathrm{m}^{-2}$ towards $2902.3 \mathrm{~kg} \mathrm{C} \mathrm{m}^{-2}$ per annum. Every year, its amount oscillates within these values (Fig. 5), while simultaneously showing spatial heterogeneity.

As shown on Fig. 5, minimal NPP was observed in years 2001 and 2008. Despite of concerted soil and water conservation programs within the watershed, there was severe drought in Ethiopia in 2001 and 2008 and more specifically, there was significantly decreasing

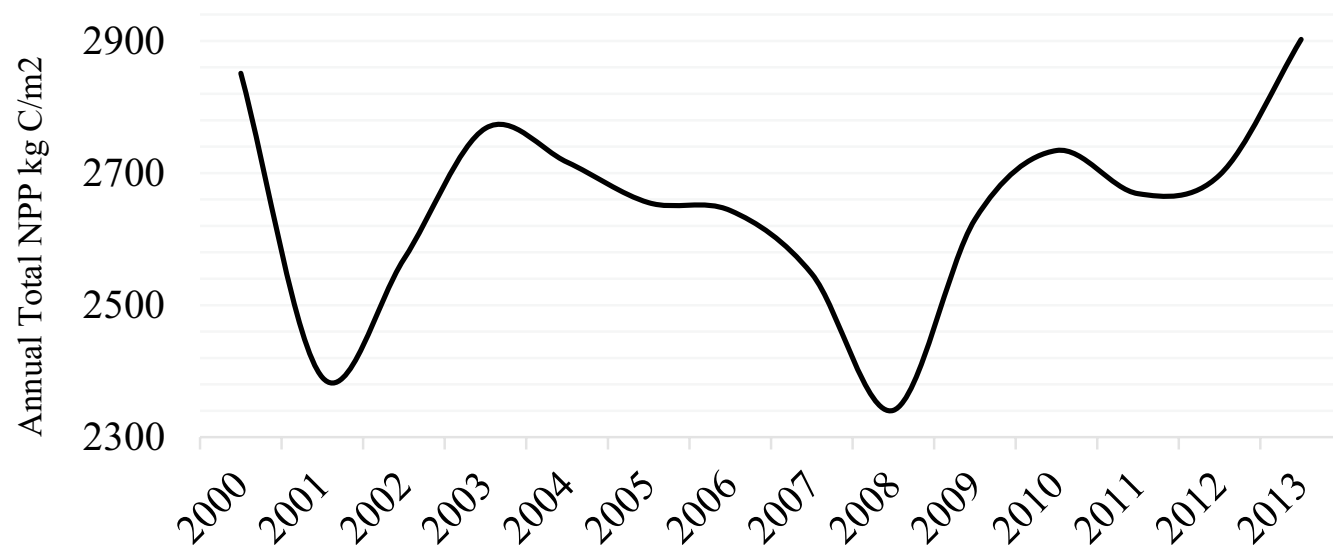

Fig. 5 Temporal changes in vegetation productivity (NPP) in Guna-Tana watershed 
precipitation pattern in the watershed (Tabari et al. 2015). This can cause vegetation stress and resultant reductions in NPP. Though there is regional variability of NPP response for drought (Hao et al. 2015), a study conducted in Europe have reported significant menacing impacts of drought on ecosystem NPP (Ciais et al. 2005). Similarly, Zhengchao et al. (2011) have reported impacts of precipitation and temperature on ecosystem NPP. The previous 17 years trend analysis has also shown that $11.8 \%$ of the watershed area have experienced significantly increasing trend in NPP while only $2.4 \%$ have experienced statistically significant reduction in NPP. The remaining area have showed a tendency of increment and reduction which is not statistically significant (Table 2). Spatially speaking, significant increasing NPP was observed in sub-Afroalpine and Alpine ecosystems around Mount Guna and some patches around Lake Tana (Fig. 6). Similar to current study, Feng et al. (2013) has reported that significantly increasing NPP was an indication of ecosystem restoration emanated from watershed intervention strategies and prevailing climatic scenarios.

Vegetation changes across slope gradient and agroecology In Ethiopia, integrated soil and water conservation programs have emphasized on the rehabilitation of degraded land at hillslopes which is highly affected by aggregate impacts of topography, erosion and farming activities. Changes in vegetation greenness have shown spatial heterogeneity across slop classes (Table 3). From observed significant increasing vegetation pattern, areas that have slope gradient greater than $20.0 \%$ have accounted only $11.8 \%$ area of the watershed. The change is manifold at low slopes which accounts $60.7 \%$. In steepest slopes, areas that have experienced increasing pattern are lower than areas that have experienced decreasing vegetation greenness. This indicates that, at the steepest slopes where there is rainfed agriculture and intense erosion hazard, still there is no sufficient regeneration of vegetation as a result of integrated soil and water conservation programs implemented in the watershed. Integrated soil and water conservation measures implemented at highland areas was basically emphasized on implementation of physical

Table 2 Watershed level trend in vegetation productivity (NPP)

\begin{tabular}{lcc}
\hline Trend type & Area in hectares & \% of total area \\
\hline Significant increase & $51,412.9$ & 11.8 \\
Significant decrease & $10,698.6$ & 2.4 \\
Non-significant increase & $236,360.5$ & 54.0 \\
Non-significant decrease & $132,544.1$ & 30.3 \\
No trend & 6637.1 & 1.6 \\
\hline
\end{tabular}

structures to halt erosion rather than integrated use of area closure and vegetative measures for vegetation rehabilitation (Genene and Abiy 2014). A study by Getachew et al. (2016) reported that even physical soil and water conservation measures installed in some watersheds is not to its technical standards to control soil erosion and foster ecosystem rehabilitation. Efficiency of ecosystem restoration and ecosystem carbon fixation was significantly affected by appropriateness of restoration mechanisms for local agro-climatic situations (Feng et al. 2013).

Similar to EVI across slope classes, there is significant decrease in NPP across steep slopes which is greater than areas that have experienced increasing trends in NPP. Vast expanses of low land areas with lower slope have also experienced significant increment which is greater than areas that have decreasing trend (Fig. 7).

Observed trends of NPP have variability across agroecological classes of the watershed (Table 4). Largest significantly increasing NPP trend was observed in Dega (mid highlands) while little patches of Wurch (Alpine) and High Wurch (Afro-Alpine) agroecologies have experienced increasing trend. Contrary to this, significantly decreasing pattern of NPP was only observed in Woina Dega (Subtropical) agroecological part. This can be attributed to expansion of agricultural and urban areas which are devoid of trees that can negatively control biosphere carbon fixation. As reported by Lemlem et al. (2017), agricultural expansion has reduced woody biomass production. More importantly, most farm plots were devoid of broad leaf woods which intern reduces NPP at areas with intensive agriculture (Binyam et al. 2015). As reported by Genene and Abiy (2014), Woina Dega (mid-highland) agroecology areas were challenged by population pressure, absence of integrated use exotic and indigenous with biophysical soil and water conservation practices. Most parts of Woina Dega and Dega agroecological areas of the watershed have experienced both tendency of increasing and decreasing trend however the changes are not statistically significant.

\section{Vegetation disturbance}

Time series vegetation disturbance index results indicate that in Guna-Tana watershed, since 2001, vegetation disturbance index values were at range of natural variability. Deviations of yearly vegetation disturbance values from long-term mean disturbance index was not far from \pm 1 standard deviations. Watershed level raster cell statistics of maximum and minimum deviations were presented in Table 5.

As indicated on Table 5, negative values were indications of tendency of positive vegetation disturbance. Though this is the truth, magnitude of vegetation regeneration is not out of the bound of natural vegetation 


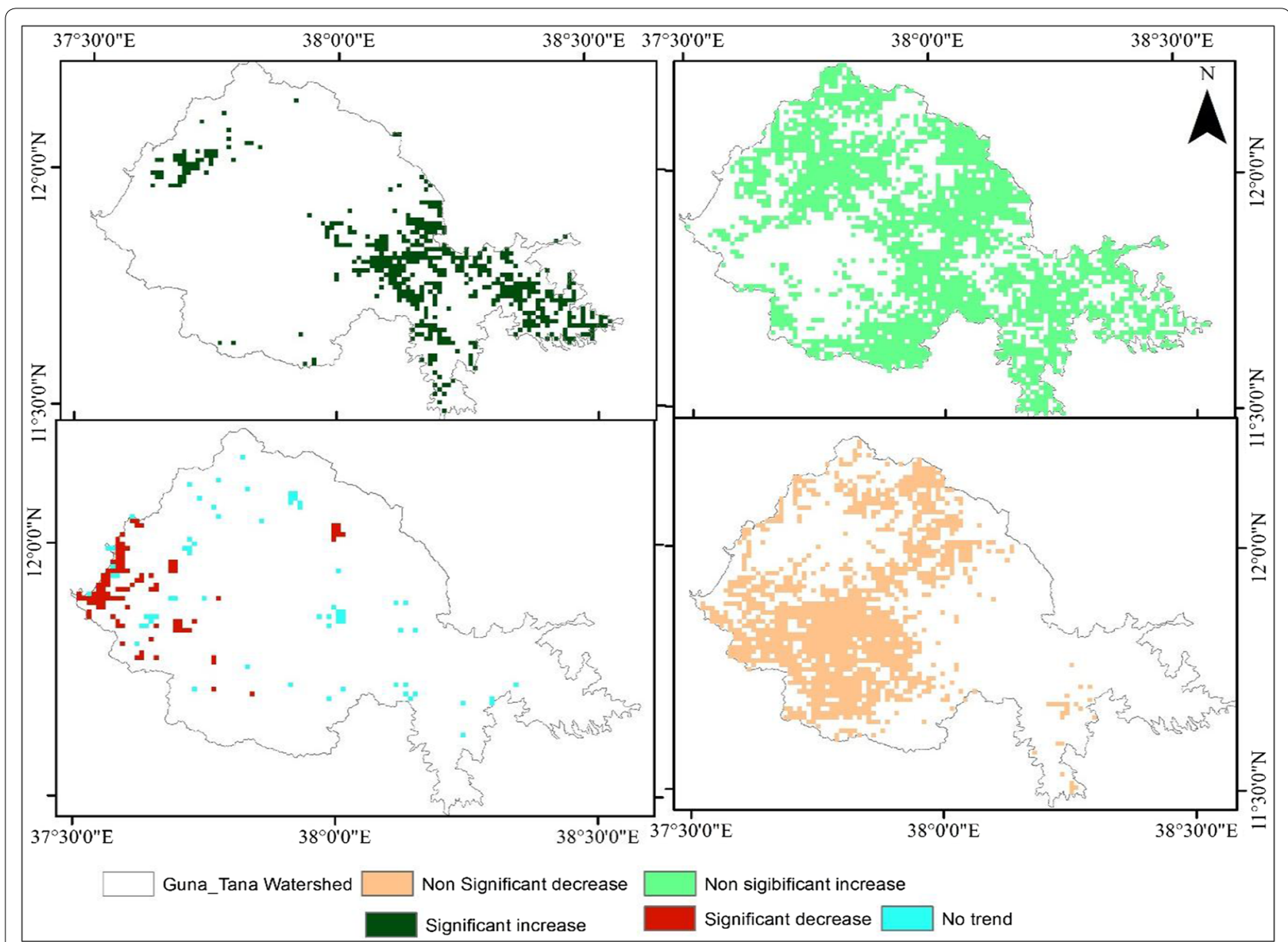

Fig. 6 Spatial patterns of trends in vegetation productivity (NPP) in Guan-Tana watershed

Table 3 Vegetation change across slope gradient

\begin{tabular}{|c|c|c|c|c|c|c|}
\hline \multirow[t]{2}{*}{ Observed trend } & \multicolumn{2}{|l|}{ Low slope } & \multicolumn{2}{|c|}{ Medium slope } & \multicolumn{2}{|c|}{ Steep slope } \\
\hline & Area (ha) & $\%$ age & Area (ha) & $\%$ age & Area (ha) & $\%$ age \\
\hline Significant increase & $25,296.5$ & 60.7 & $11,483.7$ & 27.5 & 4925.2 & 11.8 \\
\hline Significant decrease & $152,977.9$ & 58.6 & $70,908.5$ & 27.2 & $36,991.4$ & 14.2 \\
\hline Non-significant increase & $28,948.5$ & 54.4 & $15,707.1$ & 29.5 & 8521.2 & 16.0 \\
\hline Non-significant decrease & $40,978.8$ & 51.9 & $24,010.9$ & 30.4 & $13,949.4$ & 17.7 \\
\hline
\end{tabular}

variability (as its deviation is not greater than \pm longterm disturbance values). Similarly, vegetation degradation is also under the natural range of variability except in 2005, 2006 and 2016 at very small number of pixels. The spatial nature of vegetation disturbance within analysis period is presented in Fig. 5.

As indicated in Fig. 5, red colors indicated positive disturbance values which connotes tendency of decreasing vegetation while tendency of increasing vegetation regeneration have negative values with green color. As per this, northern, north eastern and eastern highlands of the watershed have showed persistent tendency of increasing vegetation but it was not beyond natural variability. During field observation it was evidenced that picks of Guna mountain were subjected for area closure conservation where vegetation is under regeneration. In the lowland parts of the watershed there is intensive agriculture where large part of biomass is crop residue and is not permanently recycled to ecosystem, since it is used for animal fodder. Similar to this finding, a study by Essayas et al. 
- Low slope $\quad$ Medium slope $\quad$ Steep slope

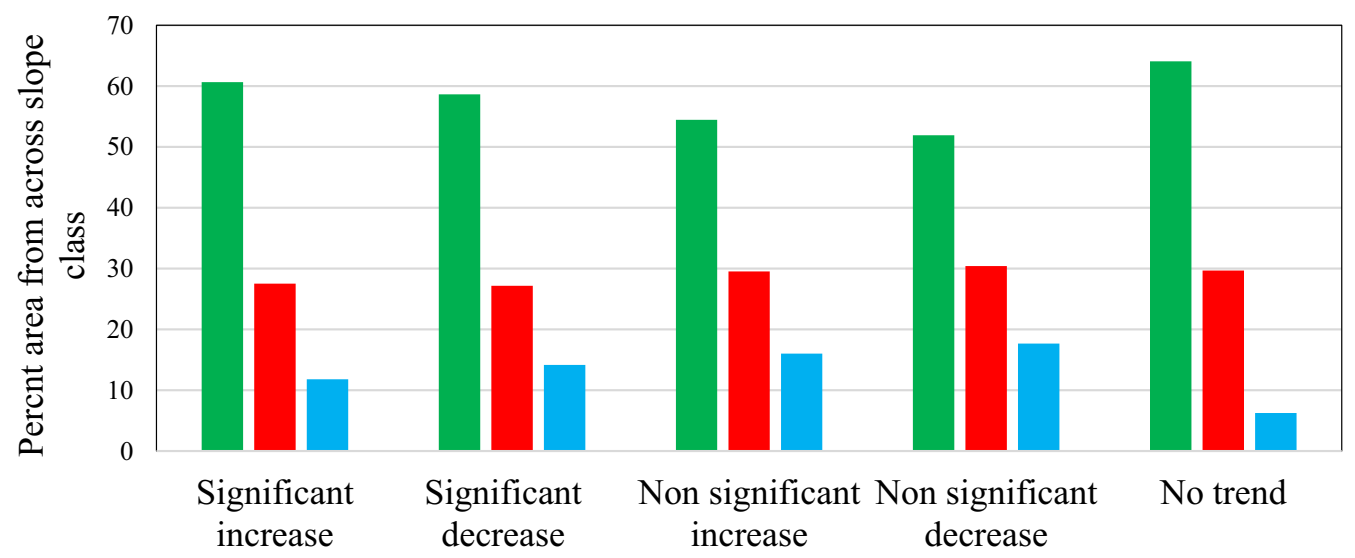

Fig. 7 Vegetation productivity (NPP) change across slope gradient

Table 4 Vegetation productivity change across agroecology

\begin{tabular}{|c|c|c|c|c|c|c|c|c|}
\hline Observed trend & WD & $\%$ area & $\mathrm{DE}$ & $\%$ area & WU & $\%$ area & HiWU & $\%$ area \\
\hline Significant increase & 5745.6 & 11.2 & $39,228.3$ & 76.3 & 6339.9 & 12.3 & 99.1 & 0.2 \\
\hline Significant decrease & $10,698.6$ & 100.0 & - & - & - & - & - & - \\
\hline Non-significant increase & $106,193.8$ & 45.0 & $114,316.8$ & 48.4 & $12,778.9$ & 5.4 & 2674.7 & 1.1 \\
\hline Non-significant decrease & $119,369.0$ & 90.1 & $11,986.4$ & 9.0 & 891.6 & 0.7 & 297.2 & 0.2 \\
\hline No change & 4061.5 & 61.2 & 2377.5 & 35.8 & 198.1 & 3.0 & - & - \\
\hline
\end{tabular}

WD is for Woinda dega, DE for Dega, WU for Wurch, Hi WU for High Wurch

Table 5 Vegetation disturbance

\begin{tabular}{lllll}
\hline Year & $\begin{array}{l}\text { Minimum deviation } \\
\text { from long term mean }\end{array}$ & $\begin{array}{l}\text { Maximum deviation } \\
\text { from long term mean }\end{array}$ & Year $\begin{array}{l}\text { Minimum deviation } \\
\text { from long term mean }\end{array}$ & $\begin{array}{l}\text { Maximum deviation from long } \\
\text { term mean }\end{array}$ \\
\hline $2003-0.69$ & 0.88 & $2010-0.74$ & 0.77 \\
$2004-0.67$ & 0.51 & $2011-0.51$ & 0.71 \\
$2005-0.59$ & 1.42 & $2012-0.54$ & 0.43 \\
$2006-0.64$ & 1.54 & $2013-0.51$ & 0.56 \\
$2007-0.49$ & 0.98 & $2014-0.52$ & 0.60 \\
$2008-0.49$ & 0.98 & $2015-0.46$ & 0.59 \\
$2009-0.54$ & 0.58 & $2016-0.46$ & 2.67 \\
\hline
\end{tabular}

(2014) in broader Blue Nile Watershed has claimed that part of Guna-Tana watershed has not experienced vegetation regeneration greater than natural variability. As results presented in Fig. 8, except small patches of the watershed, the disturbance is within range of natural variability.

\section{Discussions}

The results of this study brought some clues on previous soil and water conservation programs implemented in Guna-Tana watershed. Firstly, increasing in vegetation greenness has spatial variability that it is realized in places where area closure was implemented. Studies undertaken in some parts of Ethiopia claimed that area closure is found effective for positive vegetation reclamation and biomass fixation in the soil (Mekuria and Aynekulu 2011; Wolde and Mastewal 2013; Abera and Fitih 2015). In other words, collective physical soil and water conservation measures and community based reforestation programs were encountering problems of implementation in terms of technical specifications and 


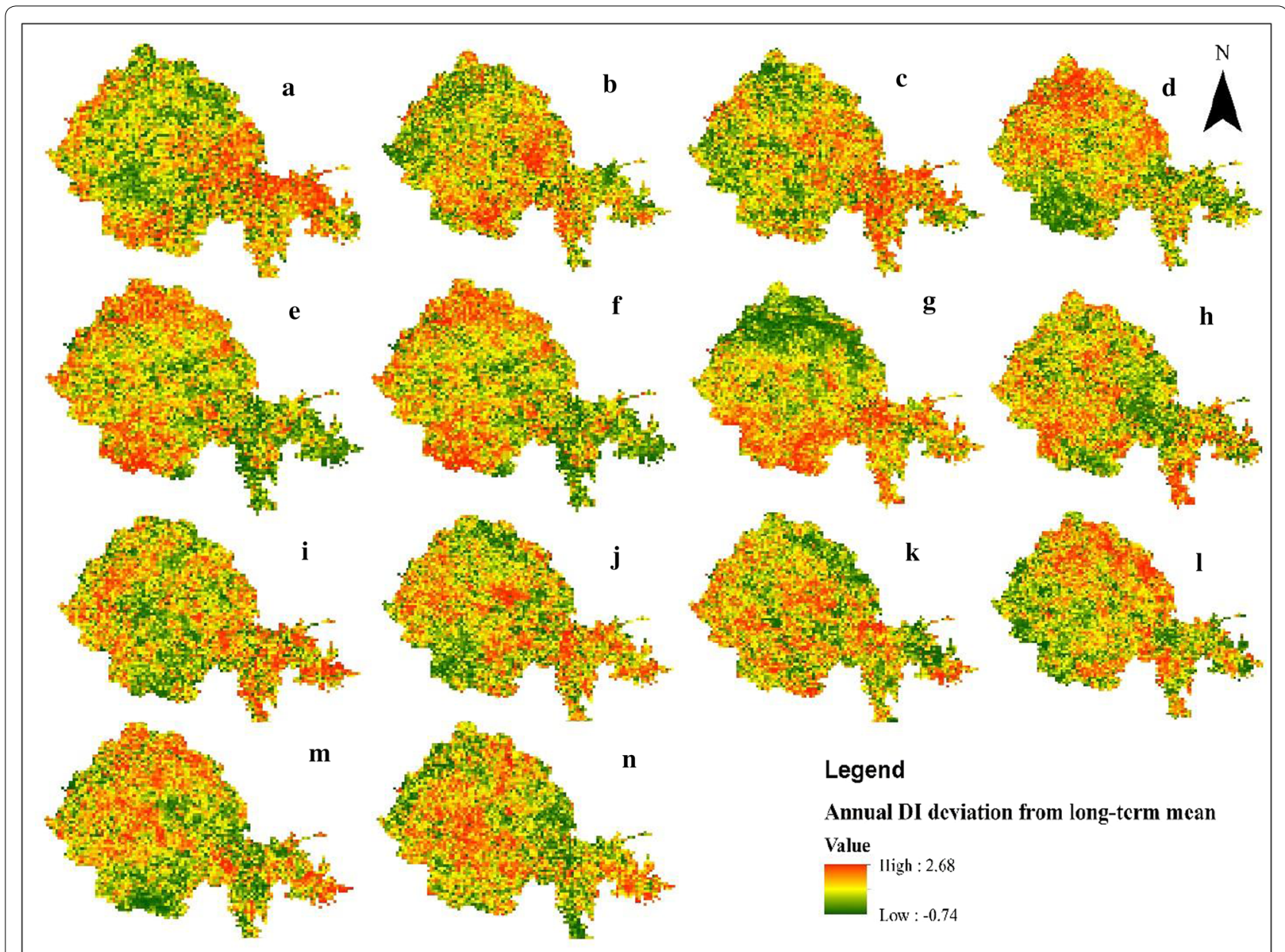

Fig. 8 Spatial patterns of vegetation disturbance in Guna-Tana watershed (a-n represent vegetation disturbance index anomaly from long-term mean disturbance from 2003 to 2016)

community acceptance (Waga et al. 2007; Abera and Fitih 2015). This hinders vast expanses of Guna tana watershed for not experiencing profoundly significant vegetation regeneration and changes in NPP which is a prime indication of ecosystem health. A study by Simane and Zaitchik (2014) supported the findings of this study. Accordingly, CNRM in northern Ethiopian highlands is reported unsustainable and even natural resources management institutions were at risk of unsustainability. Lack of institutional capacity and livelihood problems were challenging implementation process. In some watersheds where non-governmental organizations respond to support soil and water conservation programs and livelihood support system, there was intended watershed rehabilitation and positive biomass change (Essayas et al. 2014; Gebregziabher et al. 2016). This indicates that beyond inception of soil and water conservation programs in the watershed for rehabilitation and vegetation restoration, institutional capacitation and community based awareness and mainstreaming of conservation activities with rural livelihoods.

\section{Conclusion}

Though there are various soil and water conservation programs implemented in Guna-Tana watershed, within past 17 years, large areas of the watershed have not experienced uniform changes in vegetation regeneration and watershed level vegetation productivity. Very small parts of the watershed experienced statistically significant increasing vegetation regeneration trend while vast expanses have showed decreasing trend. Similarly, ecosystem productivity (NPP) has also showed similar trends with indices used to show vegetation regeneration. Analysis segregated to slope classes has showed that watershed areas with medium and steep slope have experienced decreasing pattern with large share of area than 
increasing trend. This was also evident in Wurch (Alpine) and High Wurch (Afro-alpine) agroecologies which are fragile and sensitive ecosystems. Generally speaking, except very small patches of the watershed, vegetation regeneration and watershed level ecosystem productivity trend was decreasing in vast expanses of Guna-Tana watershed. These spatial differences might be resulted from variability of watershed level intervention strategies in terms of intensity, conservation type and sustainty of the program. Results from yearly vegetation disturbance index is also an indication of unsustainty of soil and water conservation programs. In some year conservation activities were implemented in a firm way while in other year integrated soil and water conservation programs implementation was loosened. As result, positive vegetation disturbance and ecosystem rehabilitation shows a dwindling pattern of change which is not significantly greater than natural range of variability. More importantly, sensitivity of vegetation regeneration for climate variability might have hindered expected vegetation changes in the watershed. With these concluding remarks, the following recommendations were forwarded for further work. To envision positive vegetation change, ecosystem productivity and reduction of soil erosion, integrated soil and water conservation programs should focus on integrated use of area closure, biological soil and conservation strategies and reforestation measures which are tailored with respective agroecology, slope gradient and production system of the watershed. More importantly, community based soil and water conservation activities that simultaneously integrated livelihoods approach should be fostered to sustain conservation programs for long-time. Further studies should also be undertaken to study plot level effectiveness of soil and water conservation intervention strategies by using high resolution satellite imagery and field measurements. More importantly, adopted soil and water conservation programs acceptability by the community in a sustained way should also investigated by house hold level survey studies.

\begin{abstract}
Abbreviations
CNRM: Community Based Natural Resources Management; CSA: Central Statistical Agency; EVI: Enhanced Vegetation Index; EOS-HDF: Earth Observation Satellites-Hierarchical Data Format; FFT: Fast Fourier Transform; ISWC: Integrated Soil and Water Conservation Programs; ISP: Integrated Safety Net Programs; LAADS DAAC: Land and Atmospheric Archive System Distributed Active Archive Center; LST: Land Surface Temperature; MODIS: Moderate Imaging Spectrometer; MRP: Millennium Reforestation Program; NPP: Net Primary Productivity; SLM: Sustainable Land Management; SRTM DEM: Surface Radar Topography Mission Digital Elevation Model.
\end{abstract}

\section{Author details}

${ }^{1}$ Department of Geography and Environmental Studies, Debre Tabor University, Debre Tabor, Ethiopia. ${ }^{2}$ Guna Tana Integrated Field Research and Development Center, Debre Tabor, Ethiopia.

\section{Acknowledgements}

Special thanks to United States Geological Survey for freely availing satellite imagery, Mr. Abiyu Tefera (computer expert at Department of Geography and Environmental Studies, Remote Sensing and GIS laboratory) for bulk downloading of time series satellite imagery. The author acknowledges $R$ open source community for sharing image analysis packages and respective documentations. The author appreciates critical comments from anonymous reviewers that helped to improve the manuscript, Mr. Ashenafi Melese (Jimma University), Mr. Daniel Asfaw and Mr. Baymot for their proof read of the manuscript.

\section{Competing interests \\ The author declares no competing interests.}

\section{Availability of data and materials}

The data for this research can be accessed LADS ftp server ftp://ladsweb. nascom.nasa.gov/allData/6/.

\section{Consent for publication}

Not applicable.

Ethics approval and consent to participate

Not applicable.

\section{Funding}

The research has not received any fund from public or private entities.

\section{Publisher's Note}

Springer Nature remains neutral with regard to jurisdictional claims in published maps and institutional affiliations.

Received: 3 November 2017 Accepted: 7 January 2018

Published online: 15 January 2018

\section{References}

Abera A, Fitih A (2015) Lessons from watershed based climate smart agricultural practices in Jego Gudedo watershed, Ethiopia. Int I Sci Technol Res 4(12):80-85

Adugnaw B, Frankl A, Jacob M, Lanckriet S, Hendrickx H, Nyssen J (2016) Afro-alpine forest cover change on Mt. Guna (Ethiopia). In: Geophysical research abstracts, vol 18 (EGU2016-1992)

Asnake M (2017) Assessing the effectiveness of land resource management practices on erosion and vegetative cover using GIS and remote sensing techniques in Melaka watershed, Ethiopia. Environ Syst Res 6:16. https:// doi.org/10.1186/s40068-017-0093-6

Bayazit M, Önöz B (2008) To pre-whiten or not to pre-whiten in trend analysis? Hydrol Sci J 52(4):611-624. https://doi.org/10.1623/hysj.53.3.669

Binyam TH, Maeda ED, Heiskanen J, Pellikka P (2015) Reconstructing pre-agricultural expansion vegetation cover of Ethiopia. Appl Geogr 62:357-365

Chebud AY, Melesse MA (2009) Numerical modeling of the groundwater flow system of the Gumera sub-basin in Lake Tana basin, Ethiopia. Hydrol Process 23:3694-3704

Chen T, Huang Q, Liu M, Li M, Qu L, Deng S, Chen D (2017) Decreasing net primary productivity in response to urbanization in Liaoning Province, China. Sustainability 9:162. https://doi.org/10.3390/su9020162

Chisholm N, Tassew W (2012) Managing watersheds for resilient livelihoods in Ethiopia. OECD, Development Co-operation Report 2012. OECD Publishing, Paris. https://doi.org/10.1787/dcr-2012-15-en

Ciais P, Reichstein M, Viovy N, Granier A, Ogee J, Allard V, Aubinet M (2005) Europe-wide reduction in primary productivity caused by the heat and drought in 2003. Nature 437:529-533

CSA (2004) National population statistical abstract. CSA, Addis Ababa

CSA, EDRI, IFPRI (2006) Atlas of Ethiopian rural economy. CSA, EDRI, IFPRI, Addis Ababa

Donald WM, Jean S, Steven AD, Jon BH (2011) Statistical analysis for monotonic trends, Tech Notes 6, November 2011. Developed for U.S. Environmental Protection Agency by Tetra Tech, Inc., Fairfax, VA, 2011. 
https://www.epagov/polluted-runoff-nonpoint-source-pollution/ nonpointsource-monitoringtechnical-notes

Eve M, Whitford GW, Havstadt MK (1999) Applying satellite imagery to triage assessment of ecosystem health. Environ Monit Assess 54:205-227

Essayas KA, Fasikaw, AZ, Amy SC, Seifu AT, Muhammed E, William DP, Tammo SS (2014) Monitoring state of biomass recovery in the Blue Nile Basin using image-based disturbance index. In: Melesse AM et al. (eds) Nile River Basin. Springer International Publishing, Cham. https://doi. org/10.1007/978-3-319-02720-3_13

Feng X, Fu B, Lu N, Zeng Y, Wu B (2013) How ecological restoration alters ecosystem services: an analysis of carbon sequestration in China's Loess Plateau. Sci Rep 3:2846. https://doi.org/10.1038/srep02846

Fensholt R, Sandholt I, Rasmussen SM, Stisen S, Diouf A (2006) Evaluation of satellite based primary production modelling in the semi-arid Sahel. Remote Sens Environ 105:173-188

Fikir A, Nurhussen T, Nyssen J, Atkilt G, Amanuel Z, Mintesinot B, Deckers J, Poesen J (2009) The impacts of watershed management on land use and land coverdynamics in Eastern Tigray (Ethiopia). Resour Conserv Recycl 53:192-198

Gebregziabher G, Abera DA, Gebresamuel G, Giordano M, Langan S (2016) An assessment of integrated watershed management in Ethiopia. International Water Management Institute (IWMI), Colombo. (IWMI Working Paper 170). https://doi.org/10.5337/2016.214

Genene TM, Abiy G (2014) Review on overall status of soil and water conservation system and its constraints in different agro ecology of southern Ethiopia. J Nat Sci Res 4(7):59-69

Getachew E, Getachew F, Mulatie M, Assefa MM (2016) Evaluation of technical standards of physical soil and water conservation practices and their role in soil loss reduction: the case of Debre Mewi watershed, north-west Ethiopia. In: Melesse MA, Abtew W (eds) Landscape dynamics, soils and hydrological processes in varied climates. Springer International Publishing, Cham. https://doi.org/10.1007/978-3-319-18787-7_35

Gete Z, Hurni H (2001) Implications of land use and land cover dynamics for mountain resource degradation in the northwestern Ethiopian highlands. Mt Res Dev 21(2):184-191

Hao W, Guohua L, Zongshan L, Xin Y, Meng W, Li G (2015) Impacts of climate change on net primary productivity in arid and semiarid regions of China. Chin Geogr Sci. https://doi.org/10.1007/s11769-015-0762-1

Helsel RD, Hirsch MR (1992) Statistical methods in water resources: studies in environmental science 49. Elsevier Science Publishing, New York

Huete A, Didan K, Miura T, Rodriguez EP, Gao X, Ferreira GL (2002) Overview of the radiometric and biophysical performance of the MODIS vegetation indices. Remote Sens Environ 83:195-213

Hurni H, Kebede T, Gete Z (2005) The implications of changes in population, land use, and land management for surface runoff in the upper Nile basin area of Ethiopia. Mt Res Dev 25(2):147-154

Hurni H, Solomon A, Amare B, Berhanu D, Ludi E, Portner B, Birru Y, Gete Z (2010) Land degradation and sustainable land management in the highlands of Ethiopia. In: Hurni H, Wiesmann U (eds) Global change and sustainable development: a synthesis of regional experiences from research partnerships, vol 5. Geographica Bernensia, Bern, pp 187-207

Hurni H, Berhe WA, Chadhokar P, Daniel D, Gete Z, Grunder M, Kassaye G (2016) Soil and water conservation in ethiopia: guidelines for development agents, 2nd edn. Bern: Centre for Development and Environment (CDE), University of Bern, with Bern Open Publishing (BOP). https://doi. org/10.7892/boris.80013

Indiarto D, Sulistyawati E (2014) Monitoring net primary productivity dynamics in Java island using MODIS satellite imagery. Asian J Geoinform 14(1):1-14

Kebede W (2014) Effects of soil and water conservation measures and challenges for its adoption: Ethiopia in focus. J Environ Sci Technol 7(4):185-199

Lemlem T, Suryabhagavan KV, Sridhar G, Legesse G (2017) Land use and land cover changes and soil erosion in Yezat watershed, North Western Ethiopia. Int Soil Water Conserv Res 5(2):85-94. https://doi.org/10.1016/j. iswcr.2017.05.004

Li A, Bian J, Lei G, Huang C (2012) Estimating the maximal light use efficiency for different vegetation through the CASA model combined with timeseries remote sensing data and ground measurements. Remote Sens 4:3857-3876. https://doi.org/10.3390/rs4123857
Li Z, Xu D, Guo X (2014) Remote sensing of ecosystem health: opportunities, challenges, and future perspectives. Sensors 14:21117-21139. https://doi. org/10.3390/s141121117

Machiwal D, Jha KM (2012) Hydrologic time series analysis: theory and practice. Springer, Dordrecht

Meaza $\mathrm{H}$ (2015) the role of community based watershed management for climate change adaptation in Adwa, Central Tigray Zone. Int J Weather Clim Change Conserv Res 1(1):11-35

Mekuria W, Aynekulu E (2011) Enclosure land management for restoration of the soils in degraded communal lands in Ethiopia. Land Degrad Dev. https://doi.org/10.1002/ldr.1146

Mellander P-E, Gebrehiwot SG, Gardenas Al, Bewket W, Bishop K (2013) Summer rains and dry seasons in the upper blue Nile basin: the predictability of half a century of past and future spatiotemporal patterns. PLOS ONE 8(7):e68461. https://doi.org/10.1371/journal.pone.0068461

Mildrexler JD, Zhao M, Heinsch AF, Running WF (2007) A new satellite-based methodology for continental-scale disturbance detection. Ecol Appl 17:235-250

Mildrexler JD, Zhao M, Heinsch AF, Running WF (2009) Testing a MODIS global disturbance index across North America. Remote Sens Environ 113:2103-2117

Molla MA (2016) Integrated watershed management and sedimentation. J Environ Prot 7:490-494

Monteith J (1972) Solar radiation and productivity in tropical ecosystems. J Appl Ecol 9:747-766

Neumann M, Zhao M, Kindermann G, Hasenauer H (2015) Comparing MODIS net primary production estimates with terrestrial national forest inventory data in Austria. Remote Sens 7:3878-3906. https://doi.org/10.3390/ rs70403878

Nigussie H, Tsunekawa A, Nyssen J, Poesen J, Tsubo M, Derege TM, Schu B, Enyew A, Firew T (2015) Soil erosion and conservation in Ethiopia: a review. Prog Phys Geogr 1-25. https://doi. org/10.1177/0309133315598725

Nigussie H, Atsushi T, Jean P, Mitsuru T, Derege TM, Ayele AF, Jan N, Enyew A (2017) Comprehensive assessment of soil erosion risk for better land use planning in river basins: case study of the Upper Blue Nile River. Sci Total Environ 574:95-108

Nyssen J, Clymans W, Descheemaeker K, Poesen J, Vandecasteele I, Vanmaercke M, Zenebe A, Camp M, Haile M, Haregeweyn N, Moeyersons J, Martens K, Gebreyohannes K, Deckers J, Walraevens K (2010) Impact of soil and water conservation measures on catchment hydrological response: a case in north Ethiopia. Hydrol Process 24:1880-1895. https:// doi.org/10.1002/hyp.7628

Osman M, Sauerborn P (2001) Soil and water conservation in Ethiopia. J Soils Sediments 1(2):117-123

Pan S, Tian H, Dangal RS, Ouyang Z, Tao B, Ren W, Lu C, Running S (2014) Modeling and monitoring terrestrial primary production in a changing global environment: toward a multiscale synthesis of observation and simulation. Adv Meteorol. https://doi.org/10.1155/2014/965936

Potter SC, Randerson TJ, Field BC, Matson AP, Vitousek MP, Mooney AH, Klooster AS (1993) Terrestrial ecosystem production: a process model based on global satellite and surface data. Glob Biogeochem Cycles 7(4):811-841

Rocchini D, Metz M, Ricotta C, Landa M, Frigeri A, Neteler M (2013) Fourier transforms for detecting multitemporal landscape fragmentation by remote sensing. Int J Remote Sens 34(24):8907-8916. https://doi.org/10.1 080/01431161.2013.853896

Running SW, Nemani RR, Heinsch FA, Zhao M, Reeves M, Hashimoto H (2004) A continuous satellite-derived measure of global terrestrial production. Bioscience 54:547-560

Schmidt E, Fanaye T (2012) Household and plot level impact of sustainable land and watershed management (SLWM) practices in the Blue Nile. Ethiopia Strategy Support Program II (ESSP II) ESSP II Working Paper 42

Seleshi Y, Ermias T, Griensven A, Uhlenbrook S, Mul M, Kwast J, Zaag P (2012) Land use change and suitability assessment in the Upper Blue Nile Basin under water resources and socioeconomic constraints: a drive towards a decision support system. In: International Environmental Modelling and Software Society (iEMSs) 2012 international congress on environmental modelling and software managing resources of a limited planet, Sixth Biennial Meeting, Leipzig, Germany 
Seleshi Y, Zaag P, Mul M, Uhlenbrook S, Ermias T, Griensven A, Kwast J (2013) Coupled hydrologic and land use change models for decision making on land and water resources in the Upper Blue Nile Basin. In: Geophysical research abstracts, vol 15 (EGU2013-12838-1)

Seleshi GY, Marloes LM, Griensven A, Ermias T, Priess J, Schweitzer C, Zaag P (2016) Land-use change modelling in the Upper Blue Nile Basin. Environments 3:21. https://doi.org/10.3390/environments3030021

Setegn GS, Srinivasan R, Dargahi B (2008) Hydrological modelling in the Lake Tana Basin, Ethiopia using SWAT Model. Open Hydrol J 2:49-62

Shimeles D (2012) Effectiveness of soil and water conservation measures for land restoration in the Wello area, northern Ethiopian highlands. PhD dissertation Submitted to University of Bonn, Germany

Simane B, Zaitchik FB (2014) The sustainability of community-based adaptation projects in the Blue Nile highlands of Ethiopia. Sustainability 6:4308-4325. https://doi.org/10.3390/su6074308

Sjöström M, Zhao M, Archibald S, Arneth A, Cappelaere B, Falk U, De Grandcourt A, Hanan N, Kergoat L, Kutsch W, Merbold L, Ardö J (2013) Evaluation of MODIS gross primary productivity for Africa using eddy covariance data. Remote Sens Environ 131:275-286. https://doi.org/10.1016/j. rse.2012.12.023

Sung S, Nicklas F, Georg K, Lee KD (2016) Estimating net primary productivity under climate change by application of global forest model (G4M). J Korean Soc People Plants Environ 19(6):549-558. https://doi. org/10.11628/ksppe.2016.19.6.549

Tabari H, Taye TM, Willems P (2015) Statistical assessment of precipitation trends in the upper Blue Nile River basin. Stoch Environ Resour Risk Assess. https://doi.org/10.1007/s00477-015-1046-0

Teferi E, Uhlenbrook S, Bewket W (2015) Inter-annual and seasonal trends of vegetation condition in the Upper Blue Nile (Abay) Basin: dual-scale time series analysis. Earth Syst Dyn 6:617-636. https://doi.org/10.5194/ esd-6-617-2015

Temesgen G, Tesfahun F (2014) Evaluation of land use/land cover changes in east of lake Tana, Ethiopia. J Environ Earth Sci 4(11):49-53

Turner PD, Rifts DW, Cohen BW, Gower TS, Running WS, Zhao M, Costa HM, Kirschbaum AA, Ham MJ, Saleska RS, Ahl ED (2006) Evaluation of MODIS NPP and GPP products across multiple biomes. Remote Sens Environ 102:282-292
Waga M, Deribe G, Tilahun A, Matta D, Jermias M (2007) Challenges of collective action in soil and water conservation, the case of Gununo watershed, Southern Ethiopia. In: African crop science conference proceeding, vol 8, pp 1541-1545

Wolde M, Mastewal Y (2013) Changes in woody species composition following establishing enclosures on grazing lands on the lowlands of northern Ethiopia. Afr J Environ Sci Technol 7(1):30-40. https://doi.org/10.5897/ AJEST11.378

Woldeamlak B, Solomon A (2013) Land-use and land-cover change and its environmental implications in a tropical highland watershed, Ethiopia. Int J Environ Stud 70(1):126-139. https://doi.org/10.1080/00207233.201 2.755765

Woubet G, Dagnachew L (2011) Flood hazard and risk assessment using GIS and remote sensing in Fogera Woreda, Northwest Ethiopia. In: Melesse MA (ed) Nile River Basin. Berlin: Springer Science + Business Media. https://doi.org/10.1007/978-94-007-0689-7_9

Xiaoming F, Bojie F, Xiaojun Y, Yihe L (2010) Remote sensing of ecosystem services: an opportunity for spatially explicit assessment. Chin Geogr Sc 20(6):522-535

Yue S, Wang CY (2002) Applicability of pre-whitening to eliminate the influence of serial correlation on the MannKendall test. Water Resour Res 38(6):WR00861

Zerihun W (1999) Forests in the vegetation types of Ethiopia and their status in the geographical context. Paper presented at forest genetic resources conservation strategy development workshop, June 1999. Addis Ababa, Ethiopia

Zhengchao R, Huazhong Z, Hua S, Xiaoni L (2011) Spatio-temporal distribution pattern of vegetation net primary productivity and its response to climate change in Buryatiya Republic, Russia. J Resour Ecol 2(3):257-265. https://doi.org/10.3969/j.issn.1674-764x.2011.03.009

Zhou W, Li LJ, Mu JS, Gang CC, Sun GZ (2013) Effects of ecological restorationinduced land-use change and improved management on grassland net primary productivity in the Shiyanghe River Basin, north-west China. Grass Forage Sci 69:596-610. https://doi.org/10.1111/gfs.12073

\section{Submit your manuscript to a SpringerOpen ${ }^{\circ}$ journal and benefit from:}

- Convenient online submission

- Rigorous peer review

- Open access: articles freely available online

- High visibility within the field

Retaining the copyright to your article

Submit your next manuscript at springeropen.com 